\title{
Dimensional Clinical Personality Inventory 2: antecedents, development, and future improvements
}

Lucas de Francisco Carvalho

Giselle Pianowski

\begin{abstract}
Personality disorders (PDs) are characterized by impairments in the self and interpersonal relationships. People diagnosed with PD present distress in several areas of life. The prevalence of these disorders is 13\% in Western countries and around 7\% in Brazil. Despite the adverse outcomes related to PDs and their prevalence, these disorders tend to be undertreated in Brazil. One possible explanation is the lack of assessment scales to measure PDs' typical traits. To fill this gap and improves mental health care in Brazil, the Dimensional Clinical Personality Inventory 2 (IDCP-2) was developed, an assessment tool that follows international guidelines and considersthe Brazilian reality. This paper aimed to present the main characteristics of IDCP-2, including its antecedents, development, theoretical and empirical foundations, as well as definitions of its 12 dimensions distributed in 47 factors. We discussed ongoing clinical research, limitations, and future improvements of the IDCP-2. Although IDCP-2 helps fulfill the gap regarding PDs assessment in Brazil, actions for the continuity of research focused on the PDs traits assessmentare more than desirable, necessary for the mental health research area advance in the country.
\end{abstract}

Keywords: Self-report Scale; Clinical Decision-making; Symptom Assessment; Diagnosis; Psychometrics.

\section{RESUMO}

\section{Inventário Dimensional Clínico da Personalidade 2: antecedentes, desenvolvi- mento e aprimoramentos futuros}

Os transtornos da personalidade (TPs) são caracterizados por prejuízos no self e nas relações interpessoais. Pessoas diagnosticadas com TP apresentam angústia nas diversas áreas da vida. A prevalência desses transtornos é de $13 \%$ em países ocidentais e aproximadamente $7 \%$ no Brasil. Apesar de os desfechos negativos relacionados com TPs e da sua prevalência, esses transtornos tendem a ser subtratados no Brasil. Uma possível explicação é a falta de escalas avaliativas para mensurar os traços típicos dos TPs. Para preencher essa lacuna e incrementar os cuidados de saúde mental no Brasil, o Inventário Dimensional Clínico da Personalidade 2 (IDCP-2) foi desenvolvido, uma ferramenta avaliativa de acordo com as diretrizes internacionais e considerando a realidade brasileira. Este artigo tem como objetivo apresentar as principais características do IDCP-2, seus antecedentes, desenvolvimento, fundações teórica e empírica, e também as definições de suas 12 dimensões e os 47 fatores nas quais se subdividem. Nós apresentamos uma discussão das pesquisas clínicas em andamento, limitações e aprimoramentos futuros do IDCP-2. Embora o IDCP-2 auxilie no preenchimento da lacuna acerca da avaliação dos TPs no Brasil, esforços para a continuidade de pesquisas focando na avaliação dos traços de TPs são algo mais que desejável, são necessários para o avanço das pesquisas em saúde mental no país.

Palavras-chave: escala de autorrelato; tomada de decisão clínica; avaliação de sintomas; diagnóstico; psicometria.

\section{Sobre os autores}

L. F. C.

http://orcid.org/0000-00023274-9724

Universidade São Francisco Bragança Paulista, SP lucas@labape.com.br

G. P.

https://orcid.org/0000-0003-

4400-7151

Universidade São Francisco Bragança Paulista, SP gisellepianowski@gmail.com

\section{Direitos Autorais}

Este é um artigo de acesso aberto e pode ser reproduzido livremente, distribuído, transmitido ou modificado, por qualquer pessoa desde que usado sem fins comerciais. 0 trabalho é disponibilizado sob a licença Creative Commons CC-BY-NC.

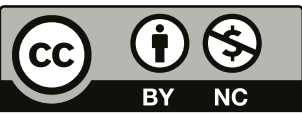




\section{H. INTERACÃO EM PSICOLOGIA}

Currently, it is estimated that over $30 \%$ of the world's population suffers from some mental disorders (Kessler \& Üstün, 2008) (MDs). MDs are the top global health challenge of the 21 st century (Collins et al., 2011) and are more frequent than previously thought (Moffitt et al., 2010). National research in the United States (US) found that $46.4 \%$ of people met the criteria for one or more MDs in their lifetimes (Kessler \& Wang, 2008), similar to what was observed in a systematic review (SR) focusing on European countries (Wittchen et al., 2011), estimating that each year $38.2 \%$ of the population suffers from mental and neurological disorders. Other SR (Steel et al., 2014), including Latin American countries as Brazil, found that $29.2 \%$ of respondents were identified as having experienced a common MD at some time during their lifetimes.

Generally, MDs have been related to adverse outcomes, as suicidal attempts and mortality. For instance, about $80 \%$ of suicide attempters in the US have a prior MD (Nock et al., 2010). According to an SR (Walker et al., 2015), including one not identified South American country, about $14.3 \%$ of worldwide deaths by year are attributable to MDs, ranking it among the most substantial causes of death in the world. In Brazil, an SR (Santos \& Siqueira, 2010) found a considerable variation in the prevalence of MDs, from $20 \%$ to $55.9 \%$, depending on sample characteristics. Interestingly, although several mental disorders (e.g., depression, schizophrenia) are addressed in this SR, no personality disorders (PDs) are mentioned, suggesting that this diagnosis is typically not accounted for in the Brazilian prevalence studies.

\section{PREVALENCE AND ASSESSMENT OF PDS}

PDs are maladaptive extremes of healthy personality patterns, resulting from predisposing temperaments and stressful circumstances (Oldham, 2017). Impairments regarding self (e.g., self-identity) and interpersonal functioning (e.g., empathy capacity) are present in people diagnosed with PDs, implying distress in several areas of life (American Psychiatric Association [APA], 2013; Skodol, 2012). The prevalence of PDs in the general population (US) is from 5 to $10 \%$ (Samuels, 2011), 13\% in Western countries (Germans et al., 2012), and higher taxes in North and South America (Huang et al., 2006). In Brazil, an epidemiologic study (Santana et al., 2018) was conducted in the São Paulo megacity with the general population, finding $6.8 \%$ of prevalence estimates. Despiting the observed prevalence of PD in several countries, including Brazil, researchers (Santana et al., 2018; Paris, 2015) agree that PDs are undertreated in Brazil.

The undertreatment issue is even more severe when considering the association between PDs and adverse outcomes. Results from an SR (Dixon-Gordon et al., 2015) indicated several deleterious health outcomes (e.g., sleep
Lucas de Francisco Carvalho e Giselle Pianowski

disturbances and other chronic health conditions) associated with PDs. The adverse outcomes related to PDs are confirmed by several studies, including but not restricted to obesity (Gerlach et al., 2016), diminish in quality of life (Cramer et al., 2006), and suicide attempts and self-harm (Krysinska et al., 2006; Yen et al., 2003).

Although undertreated, tools for assessing and diagnosing PDs and respective core traits are available in the literature. Contemporary tools are usually based on a dimensional perspective more than a categorical approach. As the categorical current official diagnosis system for PDs (e.g., DSM and ICD) has been extensively criticized, the recommendation is its replacement by a dimensional perspective (see Kotov et al., 2017; Krueger et al., 2018). This approach proposes that traits differ from person to person in terms of levels but that each individual presents all traits to some degree (Hopwood et al., 2018; Krueger et al., 2011; Samuel \& Widiger, 2008). Traits are considered pathological when reaching specific levels in the healthy-pathological continuum.

Usually presented in a self-report format and consonant with the dimensional approach, most assessment tools to measure pathological traits inform the professional on the respondent's level in the covered traits (Widiger \& Samuel, 2005). Previous evidence indicated a dangerous and delicate gap regarding the lack of tools to evaluate pathological traits in Brazil, especially in health contexts (Carvalho et al., 2010). Therefore, in the last decade, efforts were made to fulfill this gap and improve mental health care in Brazil, coming into the development of the Dimensional Clinical Personality Inventory 2 (IDCP-2) (Carvalho \& Primi, in press), an assessment tool that follows international guidelines (American Educational Research Association [AERA] et al., 2014) and takes into account the Brazilian reality. This paper aimed to present the main characteristics of IDCP-2, including its antecedents, development, and theoretical and empirical foundations. We are also offering discussion on ongoing clinical research, limitations, and future improvements of the IDCP- 2 .

\section{THE IDCP-2: ANTECEDENTS AND DEVELOPMENT}

The IDCP-2 is a revision of its predecessors, the Personality Disorders Dimensional Inventory (IDTP) (Carvalho \& Primi, 2016a) and the Dimensional Clinical Personality Inventory (IDCP) (Carvalho \& Primi, 2015). IDTP and IDCP are self-report scales to measure PDs or pathological traits. However, the former is composed of 14 dimensions, each one related to one specific PD, and IDCP is composed of 12 dimensions, reflecting broad pathological traits. Both were developed from the perspective of Millon's theory (Millon, 2011) and the diagnostic criteria of DSM-5 section 2 (APA, 2013). As each factor of the IDTP was interpreted as representing a PD more than 


\section{MLE INTERACÃO EM PSICOLOGIA}

pathological traits and, therefore, consistent with the categorical approach, the authors abandoned it, developing a measure aligned with the dimensional perspective, the IDCP.

The IDCP development was based on a production of more than 500 items (see Table 1 from Carvalho \& Primi, 2015). For example, "Usually people are not trustworthy.", presented in a 4-points Likert-like scale. IDCP's dimension are related to PDs as follows: Dependency (dependent PD), Aggressiveness (sadistic PD), Mood instability (borderline PD), Eccentricity (schizotypal PD), Attention seeking (histrionic PD), Distrust (paranoid PD), Grandiosity (narcissistic PD), Isolation (schizoid PD), Criticism avoidance (avoidant PD), Self-sacrifice (masochist PD), Conscientiousness (obsessive-compulsive PD), and Impulsiveness (antisocial PD). Psychometric properties were investigated and indicated the suitableness of IDCP for clinical purposes (Carvalho \& Primi, 2015).

Previous studies used IDCP's dimensions to investigate associations with several constructs, like intimate partner violence (Madalena et al., 2015; 2018), emotional perception (Miguel \& Pessotto, 2016), defense mechanisms (Carvalho, Reis et al., 2018), career adaptability (Carvalho, Moreira et al., 2017), five-factor model maladaptive traits (Carvalho \& Primi, 2016b), PTSD symptoms (Reis \& Carvalho, 2016; Reis et al., 2016), and depression and anxiety (Carvalho \& Arruda, 2016a). Moreover, specific groups were investigated through its dimensions, as PD outpatients (Abela et al., 2015), meditation practitioners (Carvalho \& Arruda, 2018), voluntary workers (Hiendlmayer et al., 2018), and videogame practitioners (Miguel et al., 2017).

Although showing good psychometric properties, the authors of IDCP identified some limitations. They established guidelines to improve the test (Carvalho \& Primi, in press): (a) updating according to other models other than DSM- 5 section II and Millon's theory; (b) refining its dimensions to more specific content (e.g., specific factors); and (c) equalize the number of items composing each dimension.

Based on these guidelines, IDCP were revised (Carvalho, 2018; Carvalho \& Arruda, 2016b; Carvalho \& Pianowski, 2015; Carvalho \& Sette, 2015; 2017; Carvalho et al., 2015; Carvalho, Pianowski et al., 2016; Carvalho, Sette, \& Ferrari, 2016; Carvalho \& Martins, 2017; Carvalho \& Silva, 2016; Carvalho et al., 2014; 2014a; 2014b), leading to its recent version, the IDCP-2 (CarvaIho \& Primi, in press). As a first step in the revision, the IDCP was updated according to the following models: 25 facets from DSM-5's Alternative Model for Personality Disorders (APA, 2013; Krueger et al., 2011), dimensions and prototypical descriptions from the Shedler Westen Assessment Procedure (SWAP) (Westen \& Shedler, 1999), and dimensions from Anna Clark's model (Clark, 1990). Furthermore, previous evidence suggests that
Lucas de Francisco Carvalho e Giselle Pianowski
IDCP-2 is aligned with recent taxonomic proposals in mental health (Pianowski et al., 2019), specifically, the Hierarchical Taxonomy of Psychopathology (HiTOP) (Kotov et al., 2017).

As each dimension of IDCP was revised according to DSM5 section 3, the SWAP, and Anna Clark's model, new items were developed and administered along with the original items. In addition to criteria validity evidence, using parallel analysis and exploratory factor analysis (EFA), the papers (e.g., Carvalho, 2018; Carvalho \& Sette, 2017) with focus on the review of IDCP's dimensions found specific factors composing each original dimension, as presented in Table 1.

Compared to its previous version, the 206 items that compose IDCP-2 present much more information given the incremented specificities of its factors. This improvement can be observed in the correlations between IDCP-2 total score and specific factors with other measures in comparison to the associations between IDCP's dimensions and the same external measures (for details, see the revision studies as Carvalho, 2018 and Carvalho \& Sette, 2017). Besides, the specification of each dimension in factors allows the professional to assess more information on the respondent. For instance, a person responding to IDCP could score around 2.5 (raw score, computed by the sum of items and division by the number of items) in the Grandiosity dimension (i.e., first dot in Figure 1), representing a high score (Carvalho \& Primi, in press). A high score indicates a sense of superiority, the need to be the center of attention, manipulativeness behaviors, and a lack of interest in other people's problems. However, when observing Figure 1, we can see a more detailed profile on Grandiosity factors: low (Dominance), moderate (Indifference), high (Superiority), and extreme (Need for recognition). In other words, the respondent seems not to have the same level in each Grandiosity trait (factors), showing explicitly need for recognition characteristics, but not Dominance characteristics, which implies relevant changes in clinical understanding about the patient.

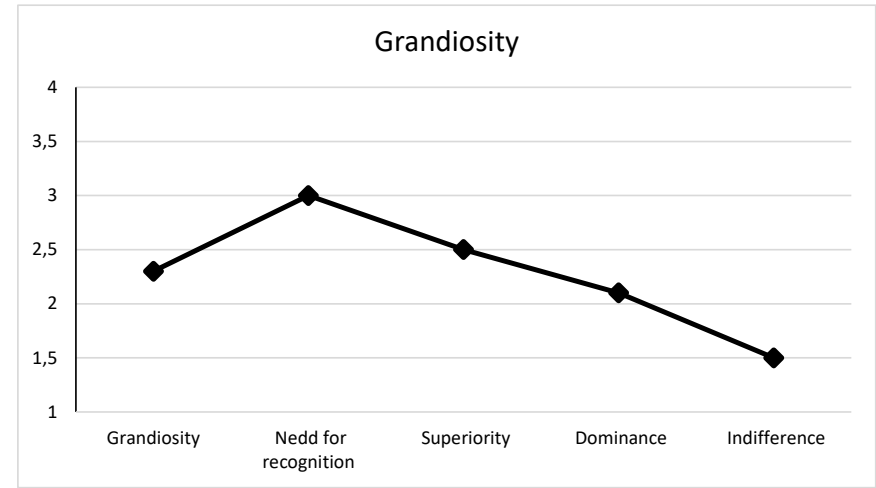

Figure 1. Example of IDCP-2 Grandiosity and its factors' profile. 
Table 1. IDCP-2 dimensions and respective factors.

\begin{tabular}{|c|c|c|c|}
\hline Dimension & Factor & $\begin{array}{l}\text { Number } \\
\text { of items }\end{array}$ & Definition \\
\hline \multirow{3}{*}{ 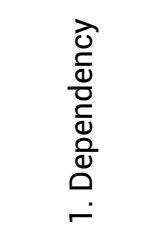 } & Self-devaluation & 7 & Self-devaluation, guilt, and feelings of incapacity. \\
\hline & $\begin{array}{l}\text { Abandonment } \\
\text { Avoidance }\end{array}$ & 6 & Anxiety of separation and fear of being abandoned. \\
\hline & Insecurity & 5 & $\begin{array}{l}\text { Submission and constant need for others to make } \\
\text { decisions and provide directions. }\end{array}$ \\
\hline \multirow{2}{*}{ 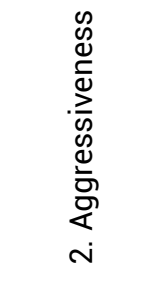 } & Antagonism & 8 & $\begin{array}{l}\text { Aggressive conduct, general interest in aggression, } \\
\text { and repressive and imposing conduct. }\end{array}$ \\
\hline & Violence & 8 & $\begin{array}{l}\text { Physical aggression, including uncontrolled anger, } \\
\text { and physically and morally aggressive behavior to others. }\end{array}$ \\
\hline \multirow{3}{*}{ 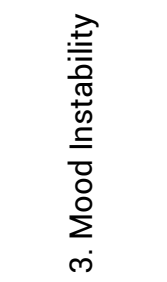 } & Vulnerability & 6 & $\begin{array}{l}\text { Emotional lability, recklessness, feelings of guilt, loss of control, } \\
\text { and tendency to hurt. }\end{array}$ \\
\hline & Anxious Worry & 6 & $\begin{array}{l}\text { Anxiety and exaggerated worry about the future and } \\
\text { about having the support of people. }\end{array}$ \\
\hline & Hopelessness & 4 & Feelings of sadness, discouragement, and suicidal thoughts. \\
\hline \multirow{6}{*}{ 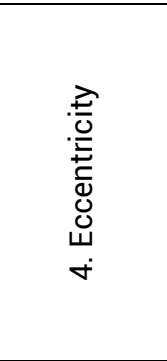 } & $\begin{array}{l}\text { Interpersonal } \\
\text { Detachment }\end{array}$ & 3 & Detachment, disinterest, and maladjustment to interpersonal relationships. \\
\hline & Eccentric Style & 3 & The perception that others see him/her as a stranger. \\
\hline & Paranormality & 3 & Beliefs in supernatural phenomena and paranormal experiences. \\
\hline & Persecuteness & 3 & Belief in being the target of secret plans and about being secretly monitored. \\
\hline & Depersonalization & 3 & Detachment from reality, including feelings of unreality and identity confusion. \\
\hline & $\begin{array}{c}\text { Emotional } \\
\text { Inexpressiveness }\end{array}$ & 3 & Lack of emotional inner experiences and expressions. \\
\hline \multirow{4}{*}{ 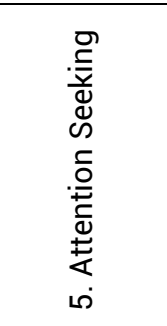 } & $\begin{array}{l}\text { Seduction and } \\
\text { Manipulation }\end{array}$ & 3 & Manipulative behavior to get people's attention, seductive conduct. \\
\hline & Emotional Intensity & 3 & $\begin{array}{c}\text { Belief about having more extreme feelings than most people and } \\
\text { need to express these feelings to people. }\end{array}$ \\
\hline & $\begin{array}{l}\text { Attention } \\
\text { Seeking }\end{array}$ & 4 & $\begin{array}{l}\text { Exaggerated need to be the center of attention, } \\
\text { always being around people, and have many friends. }\end{array}$ \\
\hline & $\begin{array}{l}\text { Interpersonal } \\
\text { Superficiality }\end{array}$ & 3 & Belief in establishing close interpersonal bonds in ease and fast ways. \\
\hline \multirow{5}{*}{ 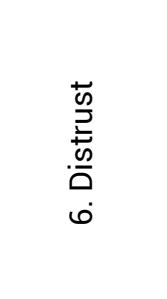 } & Suspiciousness & 5 & Persistent suspicion that others will hurt him/her. \\
\hline & $\begin{array}{c}\text { Distrust in } \\
\text { Relationships }\end{array}$ & 4 & Lack of trust in others, always avoiding new relationships. \\
\hline & Control & 3 & Inflated needs to have control over people and situations. \\
\hline & $\begin{array}{l}\text { Deception with } \\
\text { others }\end{array}$ & 3 & The belief that others will always cheat, exploit, and harm. \\
\hline & Angry Distrust & 3 & Irritability and lack of patience derived from the lack of confidence in people. \\
\hline
\end{tabular}




\begin{tabular}{|c|c|c|c|}
\hline Dimension & Factor & $\begin{array}{l}\text { Number } \\
\text { of items }\end{array}$ & Definition \\
\hline \multirow{4}{*}{ 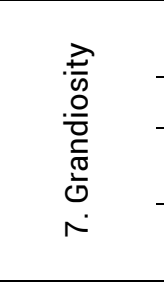 } & $\begin{array}{c}\text { Need for } \\
\text { Recognition }\end{array}$ & 4 & The necessity to be recognized for his/her qualities. \\
\hline & Superiority & 5 & A belief that others envy his/her qualities and belief in being better than people. \\
\hline & Dominance & 5 & $\begin{array}{l}\text { The belief of being capable of always getting things his/her way and } \\
\text { using manipulation to get something as he/she wants. }\end{array}$ \\
\hline & Indifference & 4 & $\begin{array}{l}\text { Lack of interest in the problems of others, } \\
\text { and believe that only his/her problems are important. }\end{array}$ \\
\hline \multirow{4}{*}{$\begin{array}{l}\frac{\sigma}{0} \\
\frac{0}{0} \\
\frac{\pi}{0} \\
\frac{0}{\infty} \\
\infty\end{array}$} & Individualism & 6 & $\begin{array}{l}\text { Preference for carrying out activities alone, sometimes including } \\
\text { irritation when in situations where contact with people is necessary. }\end{array}$ \\
\hline & Social Isolation & 4 & Preference for not establishing contact with people. \\
\hline & $\begin{array}{l}\text { Intimacy } \\
\text { Avoidance }\end{array}$ & 4 & $\begin{array}{l}\text { Avoid establishing intimate relationships and } \\
\text { do not share information about himself/herself. }\end{array}$ \\
\hline & Emotional apathy & 4 & Difficulty to get excited about everyday situations. \\
\hline \multirow{2}{*}{ 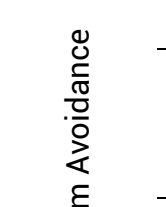 } & Anxiety & 4 & Concern about the possibility of unpleasant events and the future in general. \\
\hline & $\begin{array}{l}\text { Generalized } \\
\text { Avoidance }\end{array}$ & 10 & $\begin{array}{l}\text { Sense of embarrassment when speaking in public and when in social situations, } \\
\text { difficulty in establishing interpersonal relationships, } \\
\text { and fear of being the focus of attention. }\end{array}$ \\
\hline
\end{tabular}

Intimate

Relationships

ஸं Avoidance
4

Difficulty in becoming emotionally involved and demonstrates little interest in close friendships.

\begin{tabular}{|c|c|c|c|}
\hline \multirow{4}{*}{ 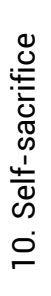 } & Masochism & 6 & $\begin{array}{l}\text { Preference for helping others more than helping himself/herself, } \\
\text { and including harm to himself/herself. }\end{array}$ \\
\hline & Depressivity & 4 & Feelings of self-worth and sadness. \\
\hline & $\begin{array}{c}\text { Self-driven } \\
\text { Hopelessness }\end{array}$ & 4 & $\begin{array}{l}\text { A belief that his/her actions will not have positive consequences, } \\
\text { and may involve guilt. }\end{array}$ \\
\hline & Submissiveness & 4 & $\begin{array}{l}\text { A belief that others are better than himself/herself and } \\
\text { a tendency to bow down before others. }\end{array}$ \\
\hline \multirow{5}{*}{ 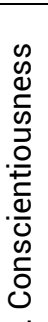 } & Need for Routine & 3 & Difficulties in dealing with changes in daily life and tasks in general. \\
\hline & $\begin{array}{l}\text { Concern with } \\
\text { Details }\end{array}$ & 3 & $\begin{array}{l}\text { Excessive preoccupation with details that, in general, } \\
\text { are not perceived by others. }\end{array}$ \\
\hline & Thoroughness & 4 & Inflated need to always reach perfection when dealing with tasks. \\
\hline & Work Compulsion & 4 & Excessive focus on work and interpersonal rigidity. \\
\hline & $\begin{array}{l}\text { Self-directed } \\
\text { Perfectionism }\end{array}$ & 4 & $\begin{array}{l}\text { An intense need to do everything with perfection, including an excessive focus } \\
\text { on himself/herself and his/her activities, with little concern for other people. }\end{array}$ \\
\hline$\check{\check{\mp}}$ & $\begin{array}{l}\text { Emotional } \\
\text { Constriction }\end{array}$ & 5 & Emotional, interpersonal, and financial restriction and formality. \\
\hline
\end{tabular}

¿ Impulsiveness

6

Impulsivity, recklessness, and quick decision-making in a passionate way.

Adventurous and reckless style, with a tendency to take
the risk and seek dangerous situations.

Deceitfulness $\quad 6 \quad$ A tendency to achieve goals by lying and controlling others.

Note. * The Inconsequence dimension was named Impulsiveness in IDCP (Carvalho, 2018). For further explanation about the changes, see Carvalho and Primi (in press). 


\section{H. INTERACÃO EM L PSICOLOGIA}

As for the third guideline, the number of items per factor varies from 3 to $10(M=4.5 ; S D=1.6)$, with most of the factors with 3 or 4 items. The variation in the number of items in IDCP was larger, from 5 to 27 . Equalizing the number of items was especially relevant for dimensions presenting a restrictive number of items in IDCP (e.g., Impulsiveness/Inconsequence dimension, with five items).

\section{ONGOING CLINICAL RESEARCH, CURRENT LIMITA- TIONS, AND FUTURE IMPROVEMENTS FOR IDCP-2}

Clinical studies are currently underway, focusing on the establishment of cutoffs with clinical relevance for each dimension (Carvalho \& Costa, 2018; Carvalho et al., 2019; Carvalho, Pianowski et al., 2017; Carvalho, Pianowski et al., 2021; Carvalho, Sette et al., 2018; Carvalho, Sette et al., 2021; Carvalho, Sette, \& Capitão, 2016), and focusing on the verification of the discriminative capacity of IDCP-2 factors according to clinical conditions (Carvalho \& Pianowski, 2019a; 2019b; Carvalho, Pianowski et al., 2018; Gonçalves et al., 2021; Machado \& Carvalho, 2021). These studies seek to verify the capacity of IDCP-2 factors to discriminate specific pathological patterns (e.g., borderline PD and Dependent PD) from other clinical and non-clinical functioning (e.g., community sample) and find optimal cutoffs for discriminating these groups. In general, these studies present cutoffs that can be used by mental health professionals in the clinical context.

Furthermore, given the context of the COVID-19 pandemic, the IDCP-2 factors have been used in a study investigating the associations between pathological traits and adherence to countermeasures against the pandemic (Carvalho, Pianowski, \& Gonçalves, 2020). Besides providing valuable information for public policies, the findings of this study reinforce the practical application of IDCP- 2 in the health context.

Hitherto evidence suggests the clinical use of IDCP-2 for assessing pathological traits. Although the IDCP- 2 is among the self-report scales for measuring pathological traits most used in scientific research in Brazil (Carvalho, Gomes, \& Silva, 2021), we must weigh the main limitations of this clinical tool. First, as a self-report, it demands some degree of self-knowledge, as the person must recognize what he/she is prompt to do or not, beliefs, feelings, and so on. This characteristic of self-report inventories is also related to the educational level, i.e., the respondent must understand the sentences well enough; otherwise, the scores observed cannot be trusted. Third, although each IDCP-2 factor may be administered independently, some respondents may find it tiring to answer the complete set with 206 items, leading to some not responding as carefully as desirable.
Lucas de Francisco Carvalho e Giselle Pianowski

A fourth limitation in the administration of IDCP-2 in Brazil is less related to the inventory itself and more to the practice currently held in the country. This limitation concerns the restrictive use, by psychologists, of any instrument considered as a "psychological test" by the Federal Council of Psychology (CFP). This is the case with IDCP-2. Resolution number 9 of the CFP (Conselho Federal de Psicologia [CFP], 2018) states that "the use of psychological methods and techniques is a restricted conduct of the psychologist" (p. 1). The Resolution claims to be based on the $1^{\circ}$ paragraph of article 13 , of Law $n^{\circ} 4119$ of 1962 (Lei n. 4.119, 1962). However, Law n 4119 states that "It is a restricted conducted of the psychologist the use of psychological methods and techniques with the following objectives: a) psychological diagnosis; b) vocational guidance and selection; c) psycho-pedagogical orientation; d) solving adjustment problems.". In other words, what is supported by Law $n^{\circ} 4119$ is the restrictive use of psychological tests, given those four practices outlined. This understanding of Law $\mathrm{n}^{\circ} 4119$ corroborates what is clarified by Primi (2018) and the Consultation 61.981/07 of the Regional Council of Medicine of São Paulo State (ConseIho Regional de Medicina do Estado de São Paulo [CREMESP], 2008). In short, although the CFP proposes the restrictive use of any test considered by the CFP as a "psychological test," Law $n^{\circ} 4119$, which underlies the CFP Resolution number 9 , does not support the imposed restriction.

The presented limitations will hardly be solved shortly because most of it is inherent to the nature itself of self-report scales and/or personality measures. Nevertheless, like any other assessment tool, IDCP-2 needs unremitting improvements. Following, we delineated three core advances recommended for the oncoming years on the improvement and continuity of IDCP-2. First, developing strategies to acquiescence control (i.e., controlling for the tendency to agree more or to agree less when responding to self-report items; Soto et al., 2008), aiming to extract style response bias from its factors and dimensions scores. Second, seeking to make IDCP-2 available to situations where respondents typically tend to manipulate the test, trying to appear healthier (i.e., faking good) or more impaired (i.e., faking bad), forced-choice versions of the test may be a suitable format (Guenole et al., 2018). Third, continuing to keep IDCP-2 items updated, considering revising each dimension and respective factors according to HiTOP (Kotov et al., 2017), will probably help in the continuity of use of IDCP-2 in the mental health field in the future.

\section{DECLARATION OF CONFLICTS OF INTEREST}

There were no conflicts of interest. 


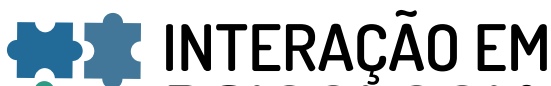 PSICOLOGIA}

\section{DECLARATION OF THE AUTHORS' CONTRIBUTION}

LFC: project management; conceptualization; writing; supervision; visualization.

GP. project management; conceptualization; writing; supervision; visualization.

\section{REFERENCES}

Abela, R. K., Carvalho, L. F., Cho, S. J. M., \& Yazigi, L. (2015). Validity Evidences for the Dimensional Clinical Personality Inventory in Outpatient Psychiatric Sample. Paidéia, 25(61), 221-228. https://doi.org/10.1590/1982-43272561201510

American Educational Research Association, American Psychological Association, \& National Council on Measurement in Education. (2014). Standards for Educational and Psychological Testing [Sixth Edition]. AERA.

American Psychiatric Association. (2013). Diagnostic and Statistical Manual of Mental Disorders [5th ed.] APA.

Lei $n^{\circ} 4.119$, de 27 de agosto de 1962. Capítulo III: Dos direitos conferidos aos diplomados. Presidência da República.

Carvalho, L. F. (2018). Review Study of the Impulsiveness Dimension of the Dimensional Clinical Personality Inventory. Universitas Psychologica, 17(1), 1-11. https://doi. org/10.11144/Javeriana.upsy17-1.rsid

Carvalho, L. F., \& Arruda, W. (2016a). Association between anxiety and depression symptoms with pathological personality traits. Revista Psicología desde el Caribe, 33, 1-18. https://doi.org/10.14482/psdc.33.2.7290

Carvalho, L. F., \& Arruda, W. (2016b). Revisão da dimensão isolamento do inventário dimensional clínico da personalidade. Temas em Psicologia, 24(1), 47-61. http://dx.doi. org/10.9788/TP2016.1-04

Carvalho, L. F., \& Costa, A. (2018). Clinical cutoff point for the Distrust dimension of the Dimensional Clinical Personality Inventory 2 (IDCP-2). Scandinavian Journal of Psychology, 59(5), 560-566. https://doi.org/10.1111/sjop. 12465

Carvalho, L. F., Gomes, G. V. A., \& Silva, E. (2021). Publications on personality disorders in Brazilian journals: a narrative review. Avaliação Psicológica, 20, 369-78. http://dx.doi. org/10.15689/ap.2021.2003.17990.11

Carvalho, L. F., \& Martins, D. da F. (2017). Revisão da dimensão desconfiança do Inventário Dimensional Clínico da Personalidade. Psico, 48(2), 152-62. https://doi. org/10.15448/1980-8623.2017.2.24823

Carvalho, L. F., \& Pianowski, G. (2015). Revision of the dependency dimension of the Dimensional Clinical Personality Inventory. Paidéia, 25(60), 57-65. https://doi. org/10.1590/1982-43272560201508
Carvalho, L. F., Pianowski, G., Costa, A. (2021). Clinical functioning and cutoff of Eccentricity dimension with psychiatric patients and non-patients. European Review of Applied Psychology, 71(4), e100672. https://doi.org/10.1016/j. erap.2021.100672

Carvalho, L. F., \& Primi R. (2015). Development and internal structure investigation of the Dimensional Clinical Personality Inventory. Psicologia: Reflexão e Crítica, 28(2), 32230. https://doi.org/10.1590/1678-7153.201528212

Carvalho, L. F., \& Primi R. (in press). Manual técnico do Inventário Dimensional Clínico da Personalidade 2 (IDCP-2) e versão triagem (IDCP-triagem). Pearson.

Carvalho, L. F., \& Primi, R. (2016a). Estudo psicométrico preliminar do Inventário Dimensional dos Transtornos da Personalidade (IDTP). Interação em Psicologia, 20, 193-205. http://dx.doi.org/10.5380/psi.v20i2.35232

Carvalho, L. F., \& Primi, R. (2016b). Prototype Matching of Personality Disorders Prototypes with the Dimensional Clinical Personality Inventory. Psicologia: Teoria e Pesquisa, 32, 1-9. https://doi.org/10.1590/0102-3772e322214

Carvalho, L. F., \& Sette, C. P. (2015). Review and verification of the psychometric properties of the mood instability dimension of the Dimensional Clinical Personality Inventory. Acta Colombiana de Psicología, 18(2), 115-27. https://doi. org/10.14718/ACP.2015.18.2.10

Carvalho, L. F., \& Sette, C. P. (2017). Revision of the Criticism Avoidance dimension of the Dimensional Clinical Personality Inventory. Estudos de Psicologia, 34(2), 219-31. https:// doi.org/10.1590/1982-02752017000200004

Carvalho, L. F., Sette, C., \& Costa, A. (2021). Toward developing clinical cut-off for the Grandiosity scale of the Dimensional Clinical Personality Inventory 2. Revista Colombiana de Psiquiatria, 1, 1-8. https://doi.org/ 10.1016/j.rcp.2020.11.015

Carvalho, L. F., \& Silva, G. F. C. (2016). Review of the self-sacrifice dimension of the dimensional clinical personality inventory. Psicologia: Reflexão e Crítica, 29(1), 6. https:// doi.org/10.1186/s41155-016-0022-z

Carvalho, L. F., \& Arruda, W. (2018). Assessment of Pathological Personality traits in Meditation Practitioners and Non-practitioners. Paidéia, 28, 1-10. https://doi.org/10.1590/ 1982-4327e2804

Carvalho, L. F., Bartholomeu D., \& Silva, M. C. R. (2010). Instrumentos para avaliação dos transtornos da personalidade no Brasil. Avaliação Psicológica, 9(2), 289-98.

Carvalho, L. F., Moreira, T. C., \& Ambiel, R. A. M. (2017). Relações entre adaptabilidade de carreira e traços patológicos da personalidade em trabalhadores brasileiros. Revista psicologia: organizações e trabalho, 17, 159-164. http://dx. doi.org/10.17652/rpot/2017.3.12931 


\section{H. INTERACÃO EM PSICOLOGIA}

Carvalho, L. F., Otoni, F., \& Junqueira, P. (2019). Obsessive-compulsive personality disorder screening cutoff for the Conscientiousness dimension of the Dimensional Clinical Personality Inventory 2. European Journal of Psychiatry, 15. https://doi.org/10.1016/j.ejpsy.2019.05.002

Carvalho, L. F., Pianowski, G., \& Gonçalves, A. P. Personality differences and the COVID-19: Are extroversion and conscientiousness personality traits associated with engagement in containment measures? Trends in Psychiatry and Psychotherapy, 42(2), 1-6. https://doi.org/10.1590/22376089-2020-0029

Carvalho, L. F., Pianowski G., \& Miguel, F. K. (2015). Revision of the aggressiveness dimension of Dimensional Clinical Personality Inventory. Psicologia: teoria e prática, 17(3), 146-63. http://dx.doi.org/10.15348/1980-6906/psicologia.v17n3p146-163

Carvalho, L. F., Pianowski G., Silveira, F. J., Bacciotti, J. T., \& Vieira, P. G. (2016). Eccentricity dimension of the Dimensional Clinical Personality Inventory: Review and psychometric properties. Estudos de Psicologia, 21(4), 359-68. https://doi.org/10.5935/1678-4669.20160035

Carvalho, L. F., \& Pianowski, G. (2019a). Dependency, Mood Instability, and Inconsequence traits on discriminating Borderline Personality Disorder. Trends in Psychiatry and Psychotherapy, 41(1), 78-82. https://doi.org/10.1590/22376089-2018-0010

Carvalho, L. F., \& Pianowski, G. (2019b). Differentiating borderline personality disorder and bipolar disorder through emotional dependency, emotional instability, impulsiveness and aggressiveness traits. European Journal of Psychiatry, 33(2), 91-95. https://doi.org/10.1016/j.ejpsy.2019.03.001

Carvalho, L. F., Pianowski, G., \& Gonçalves, A. P. (2018). Dimensional clinical personality inventory-2: investigating key factors on the assessment of dependent personality disorder. Psychology Health \& Medicine, 24(6), 732-738. https://doi.org/10.1080/13548506.2018.1554254

Carvalho, L. F., Reis, A. M., \& Pianowski, G. (2018). Investigating correlations between defense mechanisms and pathological personality characteristics. Revista Colombiana de Psiquiatria, 48(4), 232-243. https://doi.org/10.1016/j. rcp.2018.01.002

Carvalho, L. F., Sette, C. P., \& Ferrari, B. L. (2016). Revision of the grandiosity dimension of the Dimensional Clinical Personality Inventory and verification of its psychometric properties. Trends in Psychiatry and Psychotherapy, 38(3), 147-55. https://doi.org/10.1590/2237-6089-2015-0040

Carvalho, L. F., Sette, C. P., Primi, R., \& Capitão, C. G. (2014). Propriedades psicométricas da versão revisada da dimensão necessidade de atenção do inventário dimensional clínico da personalidade. Temas em Psicologia, 22(1), 14760. http://dx.doi.org/10.9788/TP2014.1-12
Lucas de Francisco Carvalho e Giselle Pianowski

Carvalho, L. F., Sette, C., \& Capitão, C. G. (2016). Investigation of the clinical functioning of the Attention Seeking Dimensional Clinical Personality Inventory. Psicologia, 30(1), 4960. https://doi.org/10.17575/rpsicol.v30i1.1072

Carvalho, L. F., Sette, C., \& Miguel, F. K. (2018). Investigation of the clinical functioning of the Dimensional Clinical Personality Inventory 2 criticism avoidance dimension. Trends in Psychiatry and Psychotherapy, 40, 93-103. https://doi. org/10.1590/2237-6089-2017-0038

Carvalho, L. F., Souza, B. D. B, \& Primi, R. (2014a) Psychometric properties of the revised conscientiousness dimension of Inventário Dimensional Clínico da Personalidade (IDCP). Trends in Psychiatry and Psychotherapy, 36, 23-31. https:// doi.org/10.1590/2237-6089-2013-0024

Carvalho, L. F., Souza, B. D. B., \& Primi, R. (2014b) Revisão da Dimensão Conscienciosidade do Inventário Dimensional Clínico da Personalidade. CES Revista Psicologia, 7, 1-14. https://revistas.ces.edu.co/index.php/psicologia/article/ view/2676

Carvalho, L. F., Pianowski, G., \& Hauck Filho, N. (2017). Establishing a clinically relevant cutoff to the Dependency Scale from the dimensional clinical personality inventory. Psychiatry Research, 251, 26-33. https://doi.org/10.1016/j. psychres.2017.02.001

Clark, L. A. (1990). Toward a consensual set of symptom clusters for assessment of personality disorder. In Butcher J. N., \& Spielberger C. D. (Eds.), Advances in personality assessment. Lawrence Erlbaum Associates.

Collins, P. Y., Patel, V., Joestl, S. S., March, D., Insel, T. R., Daar, A. S., Bordin, I. A., Costello, J., Durkin, M., Fairburn, C., Glass, R. I., Hall, W., Huang, Y., Hyman, S. E., Jamison, K., Kaaya, S., Kapur, S., Kleinman, A., Ogunniyi, A., Otero-Ojeda, A., Poo, M., Ravindranath, V., Sahakian, B. J., Saxena, S., Singer, P. A., Stein, D. J., Anderson, W. et al. (2011). Grand challenges in global mental health. Nature, $475,27-30$. https://doi.or$\mathrm{g} / 10.1038 / 475027 \mathrm{a}$

Conselho Federal de Psicologia. (2018). Resolução CFP $n^{\circ}$ 09/2018, de 25 de abril de 2018: Estabelece diretrizes para a realização de Avaliação Psicológica no exercício profissional da psicóloga e do psicólogo, regulamenta o Sistema de Avaliação de Testes Psicológicos - SATEPSI e revoga as Resoluções $n^{\circ} 002 / 2003, n^{\circ} 006 / 2004$ e $n^{\circ} 005 / 2012$ e Notas Técnicas n01/2017 e 02/2017.

Conselho Regional de Medicina do Estado de São Paulo. (2008) Parecer $n^{\circ}$ 61981. Restrição prevista na Resolução CFP 02/03 quanto a utilização de testes psicológicos por médicos. CREMESP.

Cramer, V., Torgersen, S., \& Kringlen, E. (2006). Personality disorders and quality of life. A population study. Comprehensive Psychiatry, 47(3), 178-84. https://doi.org/10.1016/j. comppsych.2005.06.002 


\section{H MTERAC̄OOEM LF. PSICOLOGIA}

Dixon-Gordon, K. L., Whalen, D. J., Layden, B. K., \& Chapman A. L. (2015). A systematic review of personality disorders and health outcomes. Canadian Psychology/Psychologie canadienne, 56(2),168-90. https://doi.org/10.1037/ cap0000024

Gerlach, G., Loeber, S., \& Herpertz S. (2016). Personality disorders and obesity: a systematic review. Obesity reviews, 17(8), 691-723.

Germans S., Van Heck, G. L., Hodiamont, P. P. G. (2012). Results of the search for personality disorder screening tools: clinical implications. J Clin Psychiatry, 73(2), 165-73. https://doi.org/10.1111/obr.12415

Gonçalves, A., Salvador, A. P., \& Carvalho, L. F. (2021). Investigation of the capacity of factors of the Dimensional Clinical Personality Inventory 2 for discriminating people with substance dependency. Acta Colombiana de Psicologia, 24(1), 121-29, https://doi.org/10.14718/acp.2021.24.1.11

Guenole, N., Brown, A. A., \& Cooper, A. J. (2018). Forced-choice assessment of work-related maladaptive personality traits: Preliminary evidence from an application of Thurstonian item response modeling. Assessment, 25(4), 51326. https://doi.org/10.1177/1073191116641181

Hiendlmayer, C., Sette, C., \& Carvalho, L. F. (2018). Investigação do perfil de personalidade em trabalhadores voluntários. Psicologia Revista, 27(1), 199-218. https://doi.or$\mathrm{g} / 10.23925 / 2594-3871.2018 v 27 i 1 p 199-218$

Hopwood, C. J., Kotov, R., Krueger, R. F., Watson, D., Widiger, T. A., Althoff, R. R., Ansell E. B., Bach, B., Bagby, R. M., Blais, M. A., Bornovalova, M. A., Chmielewski, M., Cicero, D. C., Conway, C., De Clercq, B., De Fruyt, F, Docherty, A. R., Eaton, N. R., Edens, J. F., Forbes, M. K., Forbush, K. T., Hengartner, M. P., Ivanova, M. Y., Leising, D., Livesley, W. J., Lukowitsky, M. R., Lynam, D. R., Markon, K. E., et al. (2018). The time has come for dimensional personality disorder diagnosis. Personality and Mental Health, 12(1), 82-86. https://doi. org/10.1002/pmh.1408

Huang, B., Grant, B. F., Dawson, D. A., Stinson, F. S., Chou, S. P., Saha, T. D., Goldstein, R. B., Smith, S. M., Ruan, W. J., \& Pickering, R. P. (2006). Race-ethnicity and the prevalence and co-occurrence of Diagnostic and Statistical Manual of Mental Disorders, Fourth Edition, alcohol and drug use disorders and Axis I and II disorders: United States, 2001 to 2002. Comprehensive Psychiatry, 47(4), 252-257. https:// doi.org/10.1016/j.comppsych.2005.11.001

Kessler, R. C., \& Wang, P. S. (2008). The Descriptive Epidemiology of Commonly Occurring Mental Disorders in the United States. Annual Review of Public Health, 29, 115-29. https:// doi.org/10.1146/annurev.publhealth.29.020907.090847

Kessler, R. C., Üstün, T. B. (2008). The WHO World Mental Health Surveys: Global Perspectives on the Epidemiology of Mental Disorders. Cambridge University Press.
Lucas de Francisco Carvalho e Giselle Pianowski

Kotov, R., Krueger, R. F., Watson, D., Achenbach, T. M., Althoff, R. R., Bagby, R. M., Brown, T. A., Carpenter, W. T., Caspi, A., Clark, L. A., Eaton, N. R., Forbes, M. K., Forbush, K. T., Goldberg, D., Hasin, D., Hyman, S. E., Ivanova, M. Y., Lynam, D. R., Markon, K., Miller, J. D., Moffitt, T. E., Morey, L. C., Mullins-Sweatt, S. N., Ormel, J., Patrick, C. J., Regier, D. A., Rescorla, L., Ruggero, C. J., et al. (2017). The Hierarchical Taxonomy of Psychopathology (HiTOP): A dimensional alternative to traditional nosologies. Journal of Abnormal Psychology, 126(4), 454-477. https://doi.org/10.1037/ abn0000258

Krueger, R. F., Derringer, J., Markon, K. E., Watson, D., \& Skodol, A. E. (2011) Initial construction of a maladaptive personality trait model and inventory for DSM-5. Psychological Medicine, 42(9), 1897-1890. https://doi.org/10.1017/ S0033291711002674

Krueger, R. F., Kotov R., Watson D., Forbes M. K., Eaton N. R., Ruggero C. J., Simms L. J., Widiger, T. A., Achenbach, T. M., Bach, B., Bagby, R. M., Bornovalova, M. A., Carpenter, W. T., Chmielewski, M., Cicero, D. C., Clark, L. A., Conway, C., DeClercq, B., DeYoung, C. G., Docherty, A. R., Drislane, L. A., First, M. B., Forbush, K. T., Hallquist, M., Haltigan, J. D., Hopwood, C. J., Ivanova, M. Y. (2018). Progress in achieving quantitative classification of psychopathology. World Psychiatry, 17(3), 282-293. https://doi.org/10.1002/wps.20566

Krysinska. K, Heller, T. S., \& De Leo, D. (2006). Suicide and deliberate self-harm in personality disorders. Current Opinion in Psychiatry, 19(1), 95-101. https://doi.org/10.1097/01. yco.0000191498.69281.5e

Machado, G. M., \& Carvalho, L. F. (2021). Investigation on the internal and external validity of the Antisocial subscale of the Dimensional Clinical Personality Inventory 2. Journal of Forensic Psychiatry and Psychology, 32(6), 917-32, https://doi.org/ 10.1080/14789949.2021.1945660

Madalena, M., Falcke, D., \& Carvalho, L. F. (2015). Violência conjugal e funcionamentos patológicos da personalidade. Arquivos Brasileiros de Psicologia, 67(2), 122-139.

Madalena, M., Falcke, D., \& Carvalho, L. F. (2018). Intimate Partner Violence: The Predictive Power of Experiences in the Family of Origin and of Personality Disorder Traits. Temas em Psicologia, 26(1), 93-109. https://doi.org/10.9788/ TP2018.1-04Pt

Miguel, F. K., \& Pessotto, F. (2016). Projective aspects on cognitive performance: distortions in emotional perception correlate with personality. Psicologia: Reflexão e Crítica, 29, 17. https://doi.org/10.1186/s41155-016-0036-6

Milton T. (2011). Disorders of personality: Introducing a DSM/ ICD spectrum from normal to abnormal. John Wiley \& Sons.

Moffitt, T. E., Caspi, A., Taylor, A., Kokaua, J., Milne, B. J., Polanczyk, G., \& Poulton, R. (2010). How common are common mental disorders? Evidence that lifetime prevalence rates are doubled by prospective versus retrospective ascertainment. Psychological Medicine, 40(6), 899-909. https://doi.org/10.1017/S0033291709991036 


\section{W NTERAC̄̃OEM H. PSICOLOGIA}

Nock, M. K., Hwang, I., Sampson, N. A., \& Kessler, R. C. (2010) Mental disorders, comorbidity and suicidal behavior: Results from the National Comorbidity Survey Replication. Molecular Psychiatry, 15(8), 868-76. https://doi. org/10.1038/mp.2009.29

Oldham, J. M. (2017). DSM Models of Personality Disorders. Current Opinion in Psychology, 21, 86-8. https://doi.org/10.1016/j.copsyc. 2017.09.010

Paris, J. A. (2015). A concise guide to personality disorders. APA.

Pianowski G., Carvalho, L. F., \& Miguel F. K. (2019). Investigating the Spectra constellations of the Hierarchical Taxonomy of Psychopathology (HiTOP) model for personality disorders based on empirical data from a community sample. Revista Brasileira de Psiquiatria, 41(2), 148-152. ttps:// doi.org/10.1590/1516-4446-2018-0015

Primi R. (2018). Avaliação Psicológica no Século XXI: de Onde Viemos e para Onde Vamos. Psicologia: Ciência e Profissão, 38, 1-11. https://doi.org/10.1590/1982-3703000209814

Reis, A. M., \& Carvalho, L. F. (2016). Traços patológicos da personalidade como preditores do Transtorno de Estresse Pós-traumático-TEPT. Psicologia em pesquisa, 10, 85-92. http://dx.doi.org/10.24879/201600100020063

Reis, A. M., Carvalho, L. F.; \& Elhai, J. D. (2016). Relationship between PTSD and pathological personality traits in the context of disasters. Psychiatry Research, 30, 91-97. http:// dx.doi.org/10.1016/j.psychres.2016.04.099

Samuel, D. B., \& Widiger, T. A. (2008). A Meta-Analytic Review of the Relationships between the Five-Factor Model and DSM-IV-TR Personality Disorders: A Facet Level Analysis. Clinical Psychology Review, 28(8), 1326-1342. http://dx. doi.org/10.1016/j.cpr.2008.07.002

Samuels, J. (2011). Personality disorders: epidemiology and public health issues. International Review of Psychiatry, 23(3), 223-33. http://dx.doi.org/10.3109/09540261.2011.588200

Santana, G. L., Coelho, B. M., Wang, Y. P., Chiavegatto Filho, A. D. P., Viana, M. C., \& Andrade, L. H. (2018). The epidemiology of personality disorders in the Sao Paulo Megacity general population. PloS One, 13(4). https://doi.org/10.1371/ journal.pone.0195581

Santos, E. G., \& de Siqueira, M. M. (2010). Prevalence of mental disorders in the Brazilian adult population: a systematic review from 1997 to 2009. Jornal Brasileiro de Psiquiatria, 59(3), 238-46. https://doi.org/10.1590/S004720852010000300011
Lucas de Francisco Carvalho e Giselle Pianowski

Skodol, A. E. (2012). Personality Disorders in DSM-5. Annual Review of Clinical Psychology, 8(1), 317-44. https://doi. org/10.1146/annurev-clinpsy-032511-143131.

Soto, C. J., John, O. P., Gosling, S. D., \& Potter J. (2008). The developmental psychometrics of big five self-reports: Acquiescence, factor structure, coherence, and differentiation from ages 10 to 20. Journal of Personality and Social Psychology, 94(4), 718. https://doi.org/10.1037/00223514.94.4.718

Steel, Z., Marnane, C., Iranpour, C., Chey, T., Jackson, J. W., Patel, V., \& Silove, D. (2014). The global prevalence of common mental disorders: a systematic review and meta-analysis 1980-2013. International Journal of Epidemiology, 43(2), 476-93. https://doi.org/10.1093/ije/dyu038

Walker, E. R., McGee, R. E., \& Druss, B. G. (2015). Mortality in Mental Disorders and Global Disease Burden Implications. JAMA Psychiatry, 72(4), 334. https://doi.org/10.1001/jamapsychiatry.2014.2502

Westen, D., \& Shedler, J. (1999). Revising and assessing Axis II, Part I: Developing a clinically and empirically valid assessment method. American Journal of Psychiatry, 156(2), 258-72. https://doi.org/10.1176/ajp.156.2.258.

Widiger, T. A, \& Samuel, D. B. (2005); Evidence-based assessment of personality disorders. Psychological Assessment, 17(3), 278-87. https://doi.org/10.1037/10403590.17.3.278

Wittchen, H. U., Jacobi, F., Rehm J., Gustavsson, A., Svensson, M., Jönsson, B., Olesen, J., Allgulander, C., Alonso, J., Faravelli, C., Fratiglioni, L., Jennum, P., Lieb, R., Maercker, A., van Os, J., Preisig, M., Salvador-Carulla, L., Simon, R., Steinhausen, H.C. (2011). The size and burden of mental disorders and other disorders of the brain in Europe 2010. European Neuropsychopharmacology, 21, 655-679. https:// doi.org/10.1016/j.euroneuro.2011.07.018

Yen, S., Shea, M. T., Pagano, M., Sanislow, C. A., Grilo, C. M., McGlashan, T. H., Skodol, A. E., Bender, D. S., Zanarini, M. C., Gunderson, J. G., \& Morey, L. C. (2003). Axis I and axis II disorders as predictors of prospective suicide attempts: findings from the collaborative longitudinal personality disorders study. Journal of abnormal psychology, 112(3), 375-381. https://doi.org/10.1037/0021-843x.112.3.375

Data de submissão: 14/06/2019

Primeira decisão editorial: 07/04/2020

Aceite em 15/09/2020 